\title{
MODEL REGRESJI LINIOWEJ W PROGNOZIE I BADANIU ZALEŻNOŚCI W RELACJI KONIUNKTURALNO-FINANSOWEJ STANÓW ZJEDNOCZONYCH A BUDŻETU PENTAGONU
}

\author{
Marcin Krupa \\ Skrzynka 67, 32-410 Dobczyce Małopolska \\ e-mail:krupa100@poczta.fm
}

\begin{abstract}
Streszczenie: Niniejsze badania stanowią kontynuację procesy weryfikacji trzech hipotez badawczych, które pretendują do roli prawa społecznego, a dokładnie prawa określającego powtarzalne mechanizmy relacji międzynarodowych. Poniższy artykuł w swej istocie weryfikuje słuszność pierwszej hipotezy, która głosi, że dynamiczny wzrost gospodarczy w USA poprzedza wzrost aktywności politycznej i militarnej tego kraju, dokonującej się w przestrzeni międzynarodowej. Badania dotychczas realizowane były w przestrzeni czasowej lat 1962-2007, w tym przypadku przestrzeń czasowa została rozszerzona na lata 1947-2013. Rozszerzona została również przestrzeń wskaźnikowa, gdzie analiza w tym wypadku operuje na nowej zmiennej.
\end{abstract}

Słowa kluczowe: wojna, USA, wzrost gospodarczy, cykl koniunkturalny, regresja, statystyka

\section{WSTĘP}

Poniższy proces badawczy dotyczy hipotezy badawczej głoszącej, że dynamiczny wzrost gospodarczy (czy też bardziej ogólnie i socjologicznie - „rozwój”) w przypadku Stanów Zjednoczonych powoduje wzrost aktywności politycznej tego kraju wyrażającej się w szczególności w aspektach militarnych. Natomiast wraz z recesją gospodarczą postępuje recesja polityczno-militarna. Stan gospodarczy uwidaczniany jest poprzez takie wskaźnikami jak „PKB”, „deficyt budżetowy” czy „stopa bezrobocia”. Natomiast aktywność militarna USA w wypadku tych analiz reprezentowana jest ,udziałem procentowym budżetu obronnego w budżecie federalnym” oraz ,udziałem procentowym nakładów na zbrojenia w wielkości realnej PKB".

Zastosowane metody badawcze i wykorzystane wskaźniki są w stanie uwidocznić słuszność hipotezy w taki sposób, że jeżeli wzrost nakładów na zbrojenia 
postępowałby proporcjonalnie do wzrostu gospodarczego, to w skali procentowej nie byłoby zmiany. Natomiast zmiana jest obecna, ponieważ wzrost gospodarczy powoduje wzrost udziału procentowego nakładów na zbrojenia. A więc - upraszczając - jeżeli wzrost gospodarczy osiągnął $2 \%$, a w tym czasie wzrost udziału nakładów na zbrojenia w budżecie federalnym wzrasta z $16 \%$ na $18 \%$, oznacza to, że realne wydatki na siły zbrojne uległy spotęgowaniu względem poziomu wzrostu gospodarczego ( $2 \%$ wzrostu wydatków na zbrojenia, jako efekt wzrostu gospodarczego $+2 \%$ zwiększenia udziału wydatków wojskowych w budżecie federalnym).

We wcześniejszych badaniach wykorzystywane były metody korelacyjne, które potwierdzały słuszność wysuniętej hipotezy, zwłaszcza w zakresie kierunkowym. Natomiast celem tych badań jest w dużej mierze dokonanie opisu uwidocznionych zależności. Analiza wykonana została przy pomocy programów obliczeniowych środowiska MS Excel i $R$.

\section{METODA BADAWCZA}

Model regresji liniowej ${ }^{1}$ jest funkcją opisującą przebieg zdarzeń pomiędzy zmienną tzw. „niezależną” (objaśniającą) a „zależną” (objaśnianą). Metodą stosowaną w znalezieniu estymatorów jest Klasyczna Metoda Najmniejszych Kwadratów. ${ }^{2} \mathrm{~W}$ metodzie tej współczynnik kierunkowy $\left(\beta_{1}\right)$ mówi ,jaki jest przeciętny przyrost wartości zmiennej zależnej na jednostkę przyrostu zmiennej niezależnej". ${ }^{3}$ Metoda ta, tworząc model liniowy, powoduje, że dane teoretyczne z modelu mogą odbiegać od danych rzeczywistych zmiennej niezależnej i wówczas powstaje tzw. „reszta”. Im reszta ta jest mniejsza tym lepiej, ponieważ oznacza to, że model dobrze dostosował się do wymiaru empirycznego. W tym momencie należy zastosować wzory na odchylenie standardowe reszt ${ }^{4}$ i współczynnik wyrazistości ${ }^{5}$ Odchylenie standardowe reszt informuje - jak było to stwierdzone - „(...) jakie są przeciętne odchylenia rzeczywistych wartości prognozowanej zmiennej od wartości teoretycznych. Im to odchylenie jest mniejsze, tym jakość dopasowania lepsza. Statystykę tę wykorzystujemy ... przy wyznaczaniu odchylenia standardowego estymatorów regresji”. ${ }^{6}$ Wynik ze wzoru

$$
\begin{array}{ll}
{ }^{1} Y_{i}=\beta+\beta_{1} x_{i}+\varepsilon_{i} \\
{ }^{2} \beta_{1}=\frac{\sum_{i=1}^{n}\left(x_{i}-\bar{x}\right)\left(y_{i}-\bar{y}\right)}{\sum_{i=1}^{n}\left(x_{i}-\bar{x}\right)^{2}}, \beta_{0}=\bar{y}-a_{1} \bar{x} \\
{ }^{3} \text { T. Górecki, op. cit., s. } 343 .
\end{array}
$$

$4 S e=\sqrt{\frac{1}{n-2} \sum_{i=1}^{n}\left(y_{i}-\widehat{y}_{l}\right)^{2}}$

${ }^{5} w=\frac{S e}{\bar{y}}$

${ }^{6}$ A. Snarska, op. cit., s. 163. 
na odchylenie standardowe reszt nie wiele nam mówi do póki nie podzielimy go przez średnią arytmetyczną zmiennej zależnej (współczynnik wyrazistości). Wówczas uzyskujemy informacje „(...) jaką częścią średniej wartości zmiennej objaśnianej jest odchylenie standardowe reszt (...)". ${ }^{7}$ Im wartość powstała z tego wzoru jest mniejsza, oznacza to, że tym dopasowanie jest lepsze. Najlepsze optymalnie wyniki to liczby poniżej 0,1 . Wówczas mamy pewność, że zmienna objaśniana jest przewidywalna, co umacnia jakość ewentualnej prognozy, jeżeli taką by zrealizować na podstawie modelu.

Istnieje możliwość dokonania oceny istotności parametrów modelu. W tym celu wykorzystywane są wartości odchyleń standardowych estymatorów parametrów (błędy standardowe). Wyróżniamy estymator $\mathrm{D}\left(\beta_{1}\right)^{8}$ oraz $\mathrm{D}\left(\mathrm{B}_{0}\right) \cdot{ }^{9} \mathrm{~B} \not e ̨ d y$ standardowe dają możliwość wyznaczenia błędów względnych,${ }^{10}$ które powinny być mniejsze niż 50\%. Istniej również możliwość przeprowadzenie testu istotności parametru $\boldsymbol{\beta}_{1}$, który odpowiada na pytanie o liniowość badanej zależności. ${ }^{11}$ Odpowiedz na to pytanie udzielić może również statystyka $F,{ }^{12}$ która oparta jest na współczynniku determinacji.

Ostatnim elementem modelu wartym uwagi jest wspólczynnik determinacji,${ }^{13}$ który jest niczym innym jak estymatorem kwadratu współczynnika korelacji między badanymi zmiennymi. Wynik, powstały w ramach operacji dokonanej przez narzędzie jakim jest współczynnik determinacji, można pomnożyć przez 100 i interpretować w kategoriach procentowych. Wielkość procentowa mówi jaka całkowita zmienność objaśnianej została wyjaśniona regresją. Poziom dopasowania powinien być niemniejszy niż $(0,5)$. Operując na współczynniku determinacji można również dokonać oceny korelacji (współczynnik korelacji

7 Ibidem, s. 164.

$8 D\left(\widehat{\beta_{1}}\right)=\frac{S e}{\sqrt{\sum_{i=1}^{n}\left(x_{i}-\bar{x}\right)^{2}}}$

${ }^{9} D\left(\widehat{\beta_{0}}\right)=S e \sqrt{\frac{1}{n}+\frac{\bar{x}^{2}}{\sum_{i=1}^{n}\left(x_{i}-\bar{x}\right)^{2}}}$

$10 \quad D_{w}=\frac{D\left(\widehat{\beta}_{l}\right)}{\left|\beta_{i}\right|}$

11 Test istotności:

Test istotności: $H_{o}: \beta_{1}=0$, brak zależności liniowej; $H_{1}: \beta_{1} \neq 0$,zależność liniowa istnieje. $t_{\text {stat }}=$ $\frac{\widehat{\beta}_{i}-0}{D\left(\widehat{\beta_{1}}\right)}$, statystyka ta ma rozklad $t-S t u d e n t a$. Hipotezę zerowa nalezy odrzucić $w$ sytuacji $t_{\alpha}<t_{\text {stat }}$

12 Test istotności:

Test istotności: $H_{o}: p^{2}=0$, brak zależności liniowej; $H_{1}: p^{2}>0$, zależność liniowa istnieje. $F_{\text {stat }}=$ $(n-2) \frac{R^{2}}{1-R^{2}}$, statystyka ta ma rozklad $F$ (Snedecora). Hipoteze zerowa należy odrzucić w sytuacji $F>$ $F_{\text {Stat }}$

$13 \quad R^{2}=\frac{\sum_{i=1}^{n}\left(\widehat{y}_{l}-\bar{y}\right)^{2}}{\sum_{i=1}^{n}\left(y_{i}-\bar{y}\right)^{2}}$ 
wielorakiej), ${ }^{14}$ która określa miarę zależności, jednakże bez podania informacji w którym kierunku ona może przebiegać.

Jak oceniać wyniki współczynnika korelacji wielorakiej? Opinie statystyków, ekonometryków, matematyków w tej materii bywają rozbieżne, gdzie jedni uznają bezwzględną konieczność interpretacji wyników poprzez pryzmat testów statystycznych, a inni - analizując właściwości czy cechy specyficzne tej miary korelacji - podają przedziały interpretujące wyniki analiz korelacyjnych. $\mathrm{Z}$ całą pewnością stwierdzić należy, że testy statystyczne mają bezwzględne zastosowanie wówczas, kiedy liczba zmiennych jest próbą większej populacji, tak jak w badaniach poparcia społecznego dla danej opcji politycznej, kiedy to nie można zapytać wszystkich. Natomiast jeżeli operujemy na wszystkich dostępnych obserwacjach, wówczas testy statystyczne wydają się być zbędne. Tak też w temacie wyników korelacyjnych właściwszym jest przeprowadzenie testów statystycznych, o ile mamy do czynienia z próbą. Jednakże w wypadku poniższych badań o próbie nie ma mowy, gdyż wykorzystane dane stanowią w dużej mierze populację generalną (wydarzenia przed 1947 rokiem mają inny model działania, gdzie USA nie są supermocarstwem - koncepcja „zmiany”). Wobec czego w tym wypadku wyniki oceniane będą wyłącznie przez względny pryzmat jaki prezentuje tabela (1).

Tabela 1. Interpretacja wyników operacji dokonanej na współczynniku korelacji wielorakiej

\begin{tabular}{|c|c|c|c|c|}
\hline $\begin{array}{c}\text { brak } \\
\text { współzależności }\end{array}$ & $\begin{array}{c}\text { mały stopień } \\
\text { współzależności }\end{array}$ & $\begin{array}{c}\text { średni stopień } \\
\text { współzależności }\end{array}$ & $\begin{array}{c}\text { wysoki stopień } \\
\text { współzależności }\end{array}$ & $\begin{array}{c}\text { bardzo wysoki stopień } \\
\text { współzależności }\end{array}$ \\
\hline$|\mathbf{r}|<0,1$ & $0,1 \leq|\mathbf{r}|<0,3$ & $0,3 \leq|\mathbf{r}|<0,6$ & $0,6 \leq|\mathbf{r}|<0,8$ & $\mathrm{r} \mid \geq 0,8$ \\
\hline
\end{tabular}

Źródło: opracowanie własne oparte na: T. Górecki, Podstawy statystyki z przykładami $w$, Wydawnictwo btc, Legionowo 2011, s. 319. A. Zeliaś, Metody statystyczne, Polskie Wydawnictwo Ekonomiczne, Warszawa 2000, s. 82. W. Ignatczyk, M. Chromińska, Statystyka: teoria i zastosowania, Wydawnictwo Wyższej Szkoły Bankowej, Poznań 1999, s. 161

\section{CECHY STATYSTYCZNE}

Tabela 2. Cechy statystyczne

\begin{tabular}{|c|c|r|r|c|c|c|c|c|c|c|c|c|}
\hline $\mathrm{n}$ & $\mathrm{t}$ & PKB & PKBpc & $\mathrm{B}$ & $\mathrm{D}$ & $\%$ WFZ & MPKB & $\begin{array}{c}\text { PKB } \\
(\mathrm{ZAG})\end{array}$ & $\begin{array}{c}\text { PKBpc } \\
(\mathrm{ZAG})\end{array}$ & $\begin{array}{c}\mathrm{B} \\
(\mathrm{ZAG})\end{array}$ & $\begin{array}{c}\mathrm{D} \\
\text { (ZAG) }\end{array}$ & $\mathrm{R}$ \\
\hline 1 & 1947 & $-1,09$ & $-2,97$ & 3,9 & 1,7 & 37,10 & b.d. & 1 & 1 & 5 & 5 & 3 \\
\hline 2 & 1948 & 4,15 & 2,37 & 3,8 & 4,5 & 30,53 & b.d. & 5 & 4 & 5 & 5 & 4,75 \\
\hline 3 & 1949 & $-0,54$ & $-2,25$ & 5,9 & 0,2 & 34,02 & b.d. & 1 & 1 & 4 & 5 & 2,75 \\
\hline 4 & 1950 & 8,71 & 6,92 & 5,3 & $-1,1$ & 32,15 & b.d. & 5 & 5 & 4 & 4 & 4,50 \\
\hline 5 & 1951 & 8,05 & 6,23 & 3,3 & 1,9 & 51,86 & b.d. & 5 & 5 & 5 & 5 & 5,00 \\
\hline 6 & 1952 & 4,07 & 2,30 & 3,0 & $-0,4$ & 68,09 & b.d. & 5 & 4 & 5 & 4 & 4,50 \\
\hline 7 & 1953 & 4,69 & 2,97 & 2,9 & $-1,7$ & 69,38 & b.d. & 5 & 4 & 5 & 4 & 4,50 \\
\hline 8 & 1954 & $-0,56$ & $-2,29$ & 5,5 & $-0,3$ & 69,53 & b.d. & 1 & 1 & 4 & 4 & 2,50 \\
\hline
\end{tabular}




\begin{tabular}{|c|c|c|c|c|c|c|c|c|c|c|c|c|}
\hline $\mathrm{n}$ & $\mathrm{t}$ & PKB & PKBpc & B & $\mathrm{D}$ & $\% \mathrm{WFZ}$ & MPKB & $\begin{array}{c}\text { PKB } \\
(\mathrm{ZAG})\end{array}$ & $\begin{array}{l}\text { PKBpc } \\
(\mathrm{ZAG})\end{array}$ & $\begin{array}{c}\mathrm{B} \\
(\mathrm{ZAG})\end{array}$ & \begin{tabular}{c|}
$\mathrm{D}$ \\
$(\mathrm{ZAG})$
\end{tabular} & $\mathrm{R}$ \\
\hline 9 & 1955 & 7,12 & 5,25 & 4,4 & $-0,7$ & 62,42 & b.d. & 5 & 5 & 4 & 4 & 4,50 \\
\hline 10 & 1956 & 2,13 & 0,34 & 4,1 & 0,9 & 60,19 & b.d. & 4 & 2 & 4 & 5 & 3,75 \\
\hline 11 & \begin{tabular}{|l|}
1957 \\
\end{tabular} & 2,10 & 0,28 & 4,3 & 0,7 & 59,26 & b.d. & 4 & 2 & 4 & 5 & 3,75 \\
\hline 12 & 1958 & $-0,73$ & $-2,36$ & 6,8 & $-0,6$ & 56,79 & b.d. & 1 & 1 & 3 & 4 & 2,25 \\
\hline 13 & \begin{tabular}{|l|}
1959 \\
\end{tabular} & 6,90 & 5,09 & 5,5 & $-2,5$ & 53,2 & b.d. & 5 & 5 & 4 & 4 & 4,50 \\
\hline 14 & 1960 & 2,56 & 0,50 & 5,5 & 0,1 & 52,16 & b.d. & 4 & 2 & 4 & 5 & 3,75 \\
\hline 15 & 1961 & 2,55 & 0,88 & 6,7 & $-0,6$ & 50,76 & b.d. & 4 & 2 & 3 & 4 & 3,25 \\
\hline 16 & 1962 & 6,11 & 4,49 & 5,5 & $-1,2$ & 48,97 & 9,2 & 5 & 5 & 4 & 4 & 4,50 \\
\hline 17 & 1963 & 4,35 & 2,86 & 5,7 & $-0,8$ & 47,97 & 8,9 & 5 & 4 & 4 & 4 & 4,25 \\
\hline 18 & 1964 & 5,76 & 4,31 & 5,2 & $-0,9$ & 46,24 & 8,5 & 5 & 5 & 4 & 4 & 4,50 \\
\hline 19 & 1965 & 6,49 & 5,17 & 4,5 & $-0,2$ & 42,8 & 7,4 & 5 & 5 & 4 & 4 & 4,50 \\
\hline 20 & 1966 & 6,59 & 5,37 & 3,8 & $-0,5$ & 43,19 & 7,7 & 5 & 5 & 5 & 4 & 4,75 \\
\hline 21 & 1967 & 2,74 & 1,63 & 3,8 & -1 & 45,33 & 8,8 & 4 & 3 & 5 & 4 & 4,00 \\
\hline 22 & 1968 & 4,90 & 3,86 & 3,6 & $-2,8$ & 45,98 & 9,4 & 5 & 4 & 5 & 4 & 4,50 \\
\hline 23 & 1969 & 3,14 & 2,13 & 3,5 & 0,3 & 44,93 & 8,7 & 4 & 4 & 5 & 5 & 4,50 \\
\hline 24 & 1970 & 0,20 & $-0,95$ & 4,9 & $-0,3$ & 41,76 & 8,1 & 2 & 1 & 4 & 4 & 2,75 \\
\hline 25 & 1971 & 3,29 & 2,00 & 5,9 & $-2,1$ & 37,53 & 7,3 & 4 & 4 & 4 & 4 & 4,00 \\
\hline 26 & 1972 & 5,26 & 4,14 & 5,6 & $-1,9$ & 43,33 & 6,7 & 5 & 5 & 4 & 4 & 4,50 \\
\hline 27 & 1973 & 5,64 & 4,64 & 4,9 & $-1,1$ & 31,21 & 5,8 & 5 & 5 & 4 & 4 & 4,50 \\
\hline 28 & \begin{tabular}{|l|}
1974 \\
\end{tabular} & $-0,51$ & $-1,43$ & 5,6 & $-0,4$ & 29,43 & 5,5 & 1 & 1 & 4 & 4 & 2,50 \\
\hline 29 & 1975 & $-0,19$ & $-1,15$ & 8,5 & $-3,3$ & 26,03 & 5,5 & 1 & 1 & 1 & 3 & 1,50 \\
\hline 30 & \begin{tabular}{|l|}
1976 \\
\end{tabular} & 5,38 & 4,36 & 7,7 & $-4,1$ & 24,09 & 5,2 & 5 & 5 & 2 & 2 & 3,50 \\
\hline 31 & 1977 & 4,60 & 3,56 & 7,1 & $-2,6$ & 23,75 & 4,8 & 5 & 4 & 2 & 4 & 3,75 \\
\hline 32 & 1978 & 5,56 & 4,45 & 6,1 & $-2,6$ & 22,78 & 4,7 & 5 & 5 & 3 & 4 & 4,25 \\
\hline 33 & \begin{tabular}{|l|}
1979 \\
\end{tabular} & 3,17 & 2,03 & 5,8 & $-1,6$ & 23,07 & 4,6 & 4 & 4 & 4 & 4 & 4,00 \\
\hline 34 & 1980 & $-0,24$ & $-1,39$ & 7,1 & $-2,6$ & 22,67 & 4,9 & 1 & 1 & 2 & 4 & 2,00 \\
\hline 35 & 1981 & 2,59 & 1,57 & 7,6 & $-2,5$ & 23,22 & 5,1 & 4 & 3 & 2 & 4 & 3,25 \\
\hline 36 & \begin{tabular}{|l|}
1982 \\
\end{tabular} & $-1,91$ & $-2,84$ & 9,7 & $-3,9$ & 24,84 & 5,7 & 1 & 1 & 1 & 3 & 1,50 \\
\hline 37 & \begin{tabular}{|l|}
1983 \\
\end{tabular} & 4,63 & 3,68 & 9,6 & $-5,9$ & 25,96 & 6,1 & 5 & 4 & 1 & 1 & 2,75 \\
\hline 38 & 1984 & 7,25 & 6,32 & 7,5 & $-4,7$ & 26,69 & 5,9 & 5 & 5 & 2 & 2 & 3,50 \\
\hline 39 & 1985 & 4,23 & 3,31 & 7,2 & -5 & 26,70 & 6,1 & 5 & 4 & 2 & 2 & 3,25 \\
\hline 40 & 1986 & 3,51 & 2,57 & 7,0 & $-4,9$ & 27,60 & 6,2 & 4 & 4 & 3 & 2 & 3,25 \\
\hline 41 & 1987 & 3,46 & 2,54 & 6,2 & $-3,1$ & 28,08 & 6,1 & 4 & 4 & 3 & 3 & 3,50 \\
\hline 42 & 1988 & 4,20 & 3,26 & 5,5 & -3 & 27,28 & 5,8 & 5 & 4 & 4 & 4 & 4,25 \\
\hline 43 & 1989 & 3,68 & 2,70 & 5,3 & $-2,7$ & 26,54 & 5,6 & 4 & 4 & 4 & 4 & 4,00 \\
\hline 44 & 1990 & 1,91 & 0,77 & 5,6 & $-3,7$ & 23,88 & 5,2 & 3 & 2 & 4 & 3 & 3,00 \\
\hline 45 & 1991 & $-0,07$ & $-1,39$ & 6,8 & $-4,4$ & 20,63 & 4,6 & 1 & 1 & 3 & 2 & 1,75 \\
\hline 46 & 1992 & 3,55 & 2,19 & 7,5 & $-4,5$ & 21,59 & 4,8 & 4 & 4 & 2 & 2 & 3,00 \\
\hline 47 & 1993 & 2,74 & 1,41 & 6,9 & $-3,8$ & 20,65 & 4,5 & 4 & 3 & 3 & 3 & 3,25 \\
\hline 48 & 1994 & 4,03 & 2,78 & 6,1 & $-2,8$ & 19,26 & 4,1 & 5 & 4 & 3 & 4 & 4,00 \\
\hline 49 & 1995 & 2,71 & 1,51 & 5,6 & $-2,2$ & 17,95 & 3,8 & 4 & 3 & 4 & 4 & 3,75 \\
\hline 50 & 1996 & 3,79 & 2,59 & 5,4 & $-1,3$ & 17,02 & 3,5 & 4 & 4 & 4 & 4 & 4,00 \\
\hline 51 & 1997 & 4,48 & 3,24 & 4,9 & $-0,3$ & 16,89 & 3,3 & 5 & 4 & 4 & 4 & 4,25 \\
\hline 52 & 1998 & 4,44 & 3,24 & 4,5 & 0,8 & 16,22 & 3,1 & 5 & 4 & 4 & 5 & 4,50 \\
\hline 53 & \begin{tabular}{|l|}
1999 \\
\end{tabular} & 4,68 & 3,49 & 4,2 & 1,3 & 16,14 & 3,0 & 5 & 4 & 4 & 5 & 4,50 \\
\hline 54 & 2000 & 4,09 & 2,96 & 4,0 & 2,3 & 16,45 & 3,0 & 5 & 4 & 5 & 5 & 4,75 \\
\hline 55 & 2001 & 0,97 & $-0,02$ & 4,7 & 1,2 & 16,35 & 3,1 & 2 & 1 & 4 & 5 & 3,00 \\
\hline
\end{tabular}




\begin{tabular}{|c|c|c|c|c|c|c|c|c|c|c|c|c|}
\hline $\mathrm{n}$ & $\mathrm{t}$ & PKB & PKBpc & $\mathrm{B}$ & $\mathrm{D}$ & $\%$ WFZ & MPKB & $\begin{array}{c}\text { PKB } \\
(\mathrm{ZAG})\end{array}$ & $\begin{array}{c}\text { PKBpc } \\
(\mathrm{ZAG})\end{array}$ & $\begin{array}{c}\mathrm{B} \\
(\mathrm{ZAG})\end{array}$ & $\begin{array}{c}\mathrm{D} \\
\text { (ZAG) }\end{array}$ & $\mathrm{R}$ \\
\hline 56 & 2002 & 1,78 & 0,82 & 5,8 & $-1,5$ & 17,33 & 3,4 & 2 & 2 & 4 & 4 & 3,00 \\
\hline 57 & 2003 & 2,80 & 1,86 & 6,0 & $-3,3$ & 18,73 & 3,7 & 4 & 3 & 4 & 3 & 3,50 \\
\hline 58 & 2004 & 3,78 & 2,85 & 5,5 & $-3,4$ & 19,87 & 3,9 & 4 & 4 & 4 & 3 & 3,75 \\
\hline 59 & 2005 & 3,34 & 2,39 & 5,1 & $-2,5$ & 20,03 & 4,0 & 4 & 4 & 4 & 4 & 4,00 \\
\hline 60 & 2006 & 2,66 & 1,69 & 4,6 & $-1,8$ & 19,65 & 4,0 & 4 & 3 & 4 & 4 & 3,75 \\
\hline 61 & 2007 & 1,77 & 0,80 & 4,6 & $-1,1$ & 20,2 & 4,4 & 3 & 2 & 4 & 4 & 3,25 \\
\hline 62 & 2008 & $-0,29$ & $-1,22$ & 5,8 & $-3,1$ & 20,65 & 4,2 & 1 & 1 & 4 & 3 & 2,25 \\
\hline 63 & 2009 & $-2,77$ & $-3,62$ & 9,3 & $-9,8$ & 18,79 & 4,6 & 1 & 1 & 1 & 1 & 1,00 \\
\hline 64 & 2010 & 2,53 & 1,68 & 9,6 & $-8,7$ & 20,06 & 4,7 & 4 & 3 & 1 & 1 & 2,25 \\
\hline 65 & 2011 & 1,60 & 0,83 & 8,9 & $-8,5$ & 19,58 & 4,6 & 3 & 2 & 1 & 1 & 1,75 \\
\hline 66 & 2012 & 2,32 & 1,56 & 8,1 & $-6,8$ & 19,16 & 4,2 & 4 & 3 & 1 & 1 & 2,25 \\
\hline 67 & 2013 & 2,21 & 1,46 & 7,4 & $-4,1$ & 18,33 & 3,8 & 4 & 3 & 2 & 2 & 2,75 \\
\hline
\end{tabular}

Źródło: The World Bank, Explore. Create. Share: Development Data, http://databank.worldbank.org/data/ home.aspx (2015-06-19). U.S. Government Publishing Office, Economic Report of the President, http://www. gpo.gov/fdsys/browse/collection.action?collectionCode=ERP (2015-06-19). Measuring Worth, Data Set, http://www.measuringworth.com/usgdp/ (2015-06-19). United States Department of Labor: Bureau of Labor Statistics, Data Base, Tables \& Calculators by Subject, http://data.bls.gov/timeseries/LNU04000000?years option=all_years\&periods_option=specific_periods\&periods=Annual+Data (2015-06-19). Inside Gov, The Historical U.S. Federal Budget, http://federal-budget.insidegov.com/ (2015-06-19).

W ramach procesu badawczego mamy do czynienia z następującymi cechami statystycznymi: „n”, to liczba zmiennych; „t”, to daty zmian; „PKB”, to Produkt Krajowy Brutto, ujęcie realne (a więc pozbawione elementu inflacyjnego), gdzie wskaźnik ten wyrażony jest w postaci procentowej zmiany wielkości między rokiem bazowym a rokiem następnym. „PKBpc”, to PKB per capita, a więc ten sam wskaźnik co poprzednio, lecz podzielony przez liczbę ludności. „B”, to stopa bezrobocia, a „D”, to deficyt budżetowy. „\%WFZ”, to udział procentowy wydatków federalnym USA przeznaczanych na zbrojenia. „MPKB”, to udział procentowy wydatków wojskowych w wielkości PKB realnego.

Kolejne zmienne, to rangi, gdzie „R” - będąc zmienną zagregowaną rang - symbolizuje pojęcie „rozwój”. Zmienne te powstały jako próba jednolitej interpretacji poszczególnych zjawisk ekonomicznych, celem otrzymania głębszej, bardziej precyzyjnej i kwantowej definicji wzrostu gospodarczego, rozumianego w kategoriach „rozwój”. Wobec czego cecha statystyczna PKB i PKB per capita reprezentuje stan dochodowy gospodarki; natomiast cecha bezrobocia ukazuje stan socjalny gospodarki, a deficyt budżetowy stan finansowy gospodarki. Tak też można mówić o kryzysie koniunkturalnym, społecznym i finansowym, gdzie zmienna „R” unifikuje przy pomocy średniej arytmetycznej ${ }^{15}$ te poszczególne i niekoniecznie jednorodne stany gospodarki, definiując bardziej obiektywnie stan gospodarki USA. Proces definiowania prezentuje poniższa tabela (3):

$$
{ }^{15} \frac{1}{n} \sum_{i=1}^{n} x_{i}
$$


Tabela 3. Kwantowa definicja stanu gospodarczego USA

\begin{tabular}{|c|c|c|c|c|}
\hline Stan & Interpretacja & PKB i PKB per capita & Bezrobocie & Deficyt budżetowy \\
\hline b. dobry & 5 & $\mathrm{x} \geq 4$ & $\mathrm{x} \leq 4$ & $\mathrm{x} \geq 0$ \\
\hline dobry & 4 & $2 \leq \mathrm{x}<4$ & $4<\mathrm{x} \leq 6$ & $0>\mathrm{x} \geq(-3)$ \\
\hline średni & 3 & $1 \leq \mathrm{x}<2$ & $6<\mathrm{x} \leq 7$ & $(-3)>\mathrm{x} \geq(-4)$ \\
\hline zły & 2 & $0<\mathrm{x}<1$ & $7<\mathrm{x} \leq 8$ & $(-4)>\mathrm{x} \geq(-5)$ \\
\hline b. zły & 1 & $\mathrm{x} \leq 0$ & $\mathrm{x}>8$ & $\mathrm{x}<(-5)$ \\
\hline
\end{tabular}

Źródło: opracowanie własne.

Dane podzielić można na dwa segmenty czasowe, a więc od 1947 roku, i od 1962 roku. Taki podział jest w pewnym względzie wynikiem dostępności statystyki, jednakże ma również swoje uzasadnienie merytoryczne. Otóż w 1962 roku miał miejsce tzw. ,kryzys kubański”, który stanowił istotne wydarzenie międzynarodowe, zmieniające w dużym względzie tok relacji zimnowojennych, normując, regulując i stabilizując je. Warto na tej podstawie zaobserwować wyniki w relacji całościowej i po roku 1962; gdzie „po”, to również okres post-zimnowojenny.

\section{MODELE REGRESJI}

Zmiennymi objaśnianymi są wskaźniki pośrednio uwidaczniające aktywność militarną Stanów Zjednoczonych (WFZ i MPKB), a zmiennymi objaśniającymi wskaźniki o charakterze ekonomicznym. Ta relacja ma swoje źródło w treści hipotezy, która stwierdza, że podstawą ciągu przyczynowo-skutkowego są zjawiska gospodarcze. Wobec czego wskaźniki ekonomiczne objaśniają jak zachowują się wskaźniki objaśniane, które interpretują procesy polityczne.

Dla przypomnienia: Współczynnik korelacji wielorakiej $(R)$, badający współzależność, oceniać należy mniej więcej w zgodzie ze założeniami prezentowanymi przez tabelę (1) - ogólnie dobry wynik to wynik większy niż 0,3 , gdzie wynik mniejszy niż 0,1 oznacza brak korelacji. Współczynnik determinacji $\left(R^{2}\right)$ określa wielkość zmienności zmiennej zależnej, która została wyjaśniona przez model regresji - wynik, którego optimum jest 1 , nie powinien być niższy niż 0,5 . Błędy standardowe $\left(\mathrm{D}\left(\beta_{\mathrm{x}}\right)\right.$ nie powinny być większe niż $50 \%$, ponieważ wówczas model nie może być zweryfikowany pozytywnie. Współczynnik wyrazistości $(w)$ odpowiada na pytanie jaką częścią średniej wartości zmiennej objaśnianej jest odchylenie standardowe reszt $(\mathrm{Se}$ ), które informuje jakie są przeciętne odchylenia rzeczywistych wartości zmiennej od wartości teoretycznych - wynik większy niż 0,1 mówi, że zmienna objaśniana jest nieprzewidywalna. Statystyka $F$, która oparta jest na rozkładzie $F$ Snedecora, odpowiada na pytanie czy istnieje liniowa zależność między zmiennymi. Statystyka $T$, która oparta jest na rozkładzie $t$-Studenta, ocenia czy parametry modelu są istotne. Obie statystyki są sobie współzależne, dlatego ich wynik prezentowane są w kolumnie „współzależność”, gdzie ZL oznacza zależność liniową i istotność parametrów, a ZN mówi o nieliniowości i nieistotności. 
Tabela 4. Model regresji WFZ 1947-2013

\begin{tabular}{|l|c|c|c|c|c|c|c|c|}
\hline \multicolumn{1}{|c|}{ Regresja } & $\beta_{0}$ & $\beta_{1}$ & $\mathrm{D}\left(\beta_{0}\right)$ & $\mathrm{D}\left(\beta_{1}\right)$ & $\mathrm{w}$ & $\begin{array}{c}\text { Zależ- } \\
\text { ność }\end{array}$ & $\mathrm{R}^{2}$ & $\mathrm{R}$ \\
\hline PKB/WFZ & 28,908 & 1,098 & $3,065(10 \%)$ & $0,765(69 \%)$ & 0,469 & $\mathrm{ZN}$ & 0,03 & 0,174 \\
\hline PKBpc/WFZ & 31,5 & 0,462 & $2,428(7 \%)$ & $0,79(170 \%)$ & 0,475 & ZN & 0,005 & 0,072 \\
\hline $\mathrm{B} / \mathrm{WFZ}$ & 56,563 & $-4,17$ & $6,224(11 \%)$ & $1,034(24 \%)$ & 0,42 & ZL & 0,2 & 0,447 \\
\hline $\mathrm{D} / \mathrm{WFZ}$ & 37,097 & 2,325 & $2,214(5 \%)$ & $0,681(29 \%)$ & 0,438 & ZL & 0,152 & 0,39 \\
\hline $\begin{array}{l}\text { PKB(ZAG)/ } \\
\text { WFZ }\end{array}$ & 27,748 & 1,231 & $5,277(19 \%)$ & $1,306(106 \%)$ & 0,473 & ZN & 0,013 & 0,116 \\
\hline $\begin{array}{l}\text { PKBpc(ZAG)/ } \\
\text { WFZ }\end{array}$ & 29,563 & 0,875 & $4,723(15 \%)$ & $1,338(152 \%)$ & 0,474 & ZN & 0,006 & 0,08 \\
\hline $\mathrm{B}(Z A G) / W F Z$ & 13,933 & 5,31 & $5,301(38 \%)$ & $1,442(27 \%)$ & 0,433 & ZL & 0,172 & 0,415 \\
\hline $\mathrm{D}(\mathrm{ZAG}) / \mathrm{WFZ}$ & 14,169 & 5,026 & $5,950(41 \%)$ & $1,567(31 \%)$ & 0,442 & ZL & 0,136 & 0,369 \\
\hline $\mathrm{R} / \mathrm{WFZ}$ & 14,839 & 5,031 & $6,911(47 \%)$ & $1,891(37 \%)$ & 0,452 & ZL & 0,098 & 0,313 \\
\hline
\end{tabular}

Źródło: opracowanie własne.

Tabela 5. Model regresji WFZ 1962-2013

\begin{tabular}{|l|c|c|c|c|c|c|c|c|}
\hline \multicolumn{1}{|c|}{ Regresja } & $\beta_{0}$ & $\beta_{1}$ & $\mathrm{D}\left(\beta_{0}\right)$ & $\mathrm{D}\left(\beta_{1}\right)$ & $\mathrm{w}$ & $\begin{array}{c}\text { Zależ- } \\
\text { ność }\end{array}$ & $\mathrm{R}^{2}$ & $\mathrm{R}$ \\
\hline PKB/WFZ & 21,589 & 1,6 & $2,337(10 \%)$ & $0,615(38 \%)$ & 0,358 & ZL & 0,119 & 0,345 \\
\hline PKBpc/WFZ & 23,49 & 1,512 & $1,876(7 \%)$ & $0,639(42 \%)$ & 0,362 & ZL & 0,1 & 0,316 \\
\hline B/WFZ & 39,335 & $-2,086$ & $5,216(13 \%)$ & $0,826(39 \%)$ & 0,359 & ZL & 0,113 & 0,336 \\
\hline D/WFZ & 29,371 & 1,047 & $2,014(6 \%)$ & $0,561(53 \%)$ & 0,369 & ZN & 0,065 & 0,254 \\
\hline $\begin{array}{l}\text { PKB(ZAG)/ } \\
\text { WFZ }\end{array}$ & 16,696 & 1,813 & $4,059(20 \%)$ & $1,004(55 \%)$ & 0,369 & ZN & 0,061 & 0,247 \\
\hline $\begin{array}{l}\text { PKBpc(ZAG)/ } \\
\text { WFZ }\end{array}$ & 18,165 & 2,536 & $3,58(19 \%)$ & $0,999(39 \%)$ & 0,359 & ZL & 0,114 & 0,337 \\
\hline B(ZAG)/WFZ & 16,972 & 2,946 & $3,736(22 \%)$ & $1,070(36 \%)$ & 0,355 & ZL & 0,131 & 0,362 \\
\hline D(ZAG)/WFZ & 19,622 & 2,062 & $4,327(22 \%)$ & $1,212(58 \%)$ & 0,371 & ZN & 0,054 & 0,233 \\
\hline R/WFZ & 12,583 & 4,067 & $4,851(38 \%)$ & $1,356(33 \%)$ & 0,351 & ZL & 0,152 & 0,39 \\
\hline
\end{tabular}

Źródło: opracowanie własne.

Tabela 6. Model regresji MPKB 1962-2013

\begin{tabular}{|l|c|c|c|c|c|c|c|c|}
\hline \multicolumn{1}{|c|}{ Regresja } & $\beta_{0}$ & $\beta_{1}$ & $\mathrm{D}\left(\beta_{0}\right)$ & $\mathrm{D}\left(\beta_{1}\right)$ & $\mathrm{w}$ & $\begin{array}{c}\text { Zależ- } \\
\text { ność }\end{array}$ & $\mathrm{R}^{2}$ & $\mathrm{R}$ \\
\hline PKB/MPKB & 4,687 & 0,221 & $0,42(8 \%)$ & $0,11(50 \%)$ & 0,064 & $\mathrm{ZN}$ & 0,073 & 0,271 \\
\hline PKBpc/MPKB & 4,951 & 0,208 & $0,336(6 \%)$ & $0,114(55 \%)$ & 0,064 & $\mathrm{ZN}$ & 0,061 & 0,248 \\
\hline $\mathrm{B} / \mathrm{MPKB}$ & 6,644 & $-0,207$ & $0,954(14 \%)$ & $0,151(73 \%)$ & 0,065 & $\mathrm{ZN}$ & 0,036 & 0,19 \\
\hline $\mathrm{D} / \mathrm{MKB}$ & 5,552 & 0,065 & $0,364(6 \%)$ & $0,101(155 \%)$ & 0,066 & $\mathrm{ZN}$ & 0,008 & 0,09 \\
\hline $\begin{array}{l}\text { PKB(ZAG)/ } \\
\text { MPKB }\end{array}$ & 4,425 & 0,25 & $0,72(16 \%)$ & $0,178(71 \%)$ & 0,065 & $\mathrm{ZN}$ & 0,038 & 0,195 \\
\hline $\begin{array}{l}\text { PKBpc(ZAG)/ } \\
\text { MPKB }\end{array}$ & 4,179 & 0,361 & $0,641(15 \%)$ & $0,179(49 \%)$ & 0,064 & $\mathrm{ZL}$ & 0,075 & 0,274 \\
\hline
\end{tabular}




\begin{tabular}{|l|c|c|c|c|c|c|c|c|}
\hline \multicolumn{1}{|c|}{ Regresja } & $\beta_{0}$ & $\beta_{1}$ & $\mathrm{D}\left(\beta_{0}\right)$ & $\mathrm{D}\left(\beta_{1}\right)$ & $\mathrm{w}$ & $\begin{array}{c}\text { Zależ- } \\
\text { ność }\end{array}$ & $\mathrm{R}^{2}$ & $\mathrm{R}$ \\
\hline $\begin{array}{l}\mathrm{B}(\mathrm{ZAG}) / \\
\text { MPKB }\end{array}$ & 4,358 & 0,312 & $0,686(15 \%)$ & $0,196(62 \%)$ & 0,065 & $\mathrm{ZN}$ & 0,048 & 0,219 \\
\hline $\begin{array}{l}\mathrm{D}(\mathrm{ZAG}) / \\
\text { MPKB }\end{array}$ & 4,947 & 0,127 & $0,778(15 \%)$ & $0,218(170 \%)$ & 0,066 & $\mathrm{ZN}$ & 0,006 & 0,082 \\
\hline R/MPKB & 3,747 & 0,473 & $0,893(23 \%)$ & $0,249(52 \%)$ & 0,064 & $\mathrm{ZN}$ & 0,067 & 0,259 \\
\hline
\end{tabular}

Źródło: opracowanie własne.

Podsumowanie wyników:

- Lepsze wyniki pojawiają się w zestawieniu ze statystyką nakładów na zbrojenia jako udziału procentowego budżetu Pentagonu w budżecie federalnym USA, niż w przypadku wskaźnika PKB.

- Najlepsze wyniki pojawiają się w relacji ze stopą bezrobocia, co dowodzić może, że administracja USA, jak również ogólnie całe zaplecze polityczne (prawdopodobnie podparte cichymi sugestiami kapitału), podejmuje aktywniej decyzję prowojenne w sytuacjach stabilizacji zawodowej amerykańskiego społeczeństwa.

- Nieco gorsze wyniki występują w badaniach od 1962 roku, co sugerować może słabnięcie badanej prawidłowości w zgodzie ze założeniem prezentowanym przez hipotezę, co pośrednio dowodzić może np. zmianie biegunów siły.

- Wyniki są na tyle dobre, że można mówić o współzależności zgodnej $\mathrm{z}$ wysuniętymi hipotezami, jednak wyniki sugerują brak dostrzeżenia innych elementów większej układanki. Wobec czego badane procesy są z dużym prawdopodobieństwem o wiele bardziej wieloczynnikowe.

- Wyniki są na tyle dobre, aby mówić o współzależności, jednak na tyle złe, że na ich podstawie (z paroma mało istotnymi wyjątkami) nie jest możliwe dokonanie precyzyjnej prognozy. Wynika to ze wspomnianej wieloczynnikowości procesów społecznych, prawdopodobnie również występowania silnej dynamiki.

- Osiągnięcie idealnego modelu w badaniu procesów międzynarodowych jest bardzo trudne, gdzie oprócz elementów wieloczynnikowości i dynamiki dochodzą prawdopodobnie takie zagadnienia jak problemy natury kwantyfikacyjnej czy amatematyczność niektórych procesów.

\section{PROGNOZA}

W tym artykule próba sformułowania wieloaspektowego matematycznego modelu predykcyjnego, adekwatnego prognozą ekonomicznym dokonywującym się na gruncie ekonometrii, zostanie pominięta. Prognoza będzie miała formę bardziej uproszczoną. Otóż jak wiadomo z tych i innych tego typu badań, „stan 
dobrego samopoczucia w gospodarce USA" (terminologia Krzysztofa Michałka) powoduje wzrost aktywności politycznej i militarnej Stanów Zjednoczonych na arenie międzynarodowej. Wiadomo również, z innych tym podobnych badań, że wzrost wspomnianej aktywności USA powoduje międzynarodową stabilizację, co objawia się mniejszą liczbą wojen. Wobec tego w kontekście prognozy należy określić trend (Metoda Najmniejszych Kwadratów) stanu gospodarki USA (w relacji z czasem), aby odnaleźć odpowiedz w temacie przyszłej projekcji zdarzeń.

Jak wiadomo najlepiej skorelowanym wskaźnikiem reprezentującym proces ekonomiczny stanu koniunkturalnego ze wskaźnikami reprezentującymi proces polityczny jakim jest wzrost aktywności międzynarodowej USA, jest stopa bezrobocia.

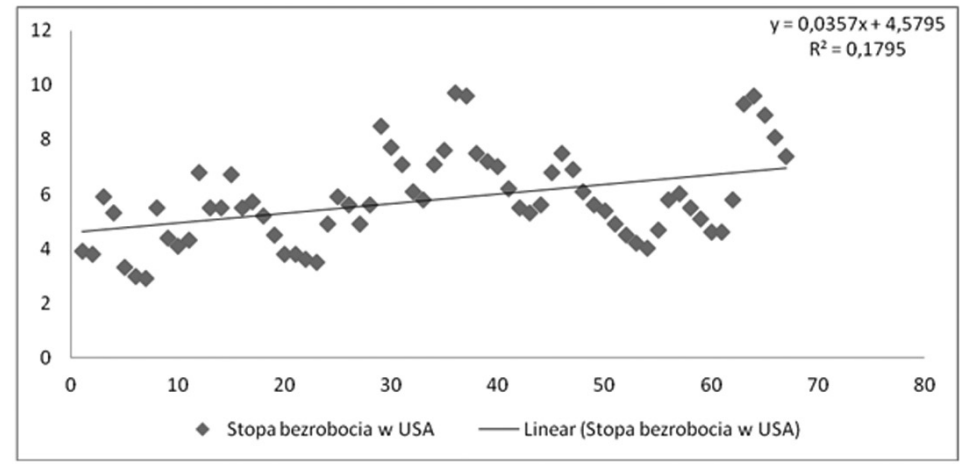

Rysunek 1. Trend stopy bezrobocia w USA w czasie (1947-2013)

Źródło: opracowanie własne.

Rysunek powyższy (1) prezentuje tendencję występującą w stopie bezrobocia w USA z wykorzystaniem danych w przedziale lat 1947-2013. Jak jest to widoczne, w Stanach Zjednoczonych stopa bezrobocia jest coraz wyższa, co oznacza, że administracja amerykańska ma coraz bardziej związane ręce w aspekcie realizacji swojej mocarstwowej polityki zagranicznej. Spójrzmy poniżej na inne wskaźniki ekonomiczne.

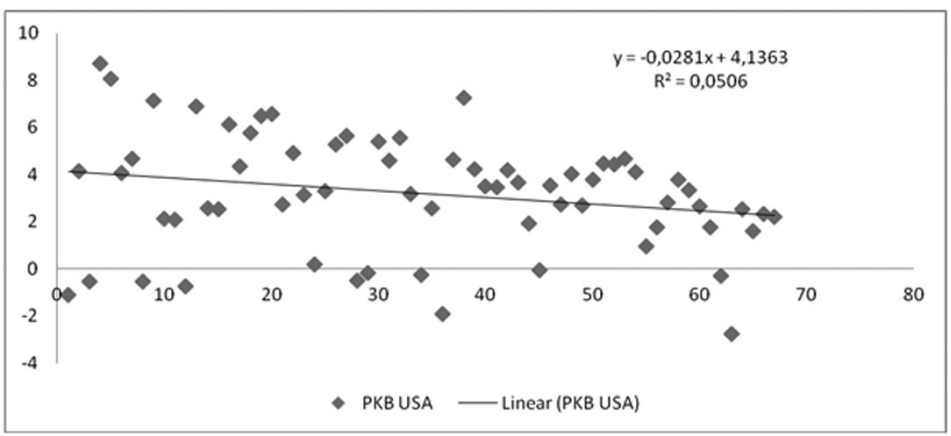

Rysunek 2. Trend zmian PKB w USA w czasie (1947-2013)

Źródło: opracowanie własne. 


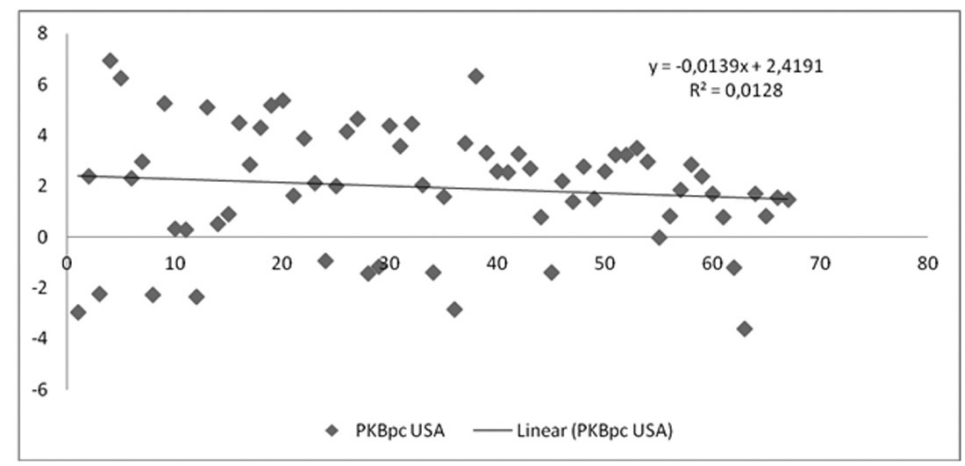

Rysunek 3. Trend zmian PKB per capita w USA w czasie (1947-2013)

Źródło: opracowanie własne.

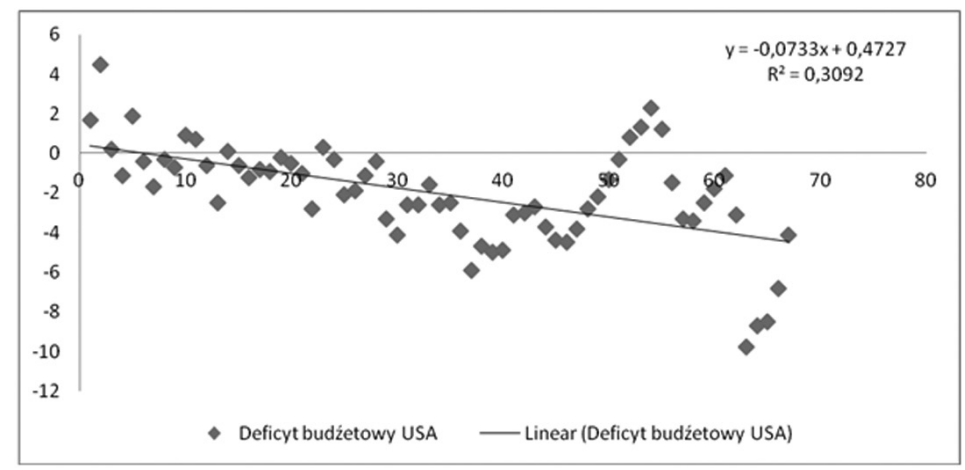

Rysunek 4: Trend zmian deficytu budżetowego w USA w czasie (1947-2013) Źródło: opracowanie własne.

Jak jest to widoczne na powyższych rysunkach $(2,3,4)$ stan amerykańskiej gospodarki w pewnym względzie z roku na rok jest coraz gorszy. Dynamika zmian wzrostowych w PKB jest coraz mniejsza, a deficyt budżetowy coraz większy. Powyższe dane, w świetle danych makroekonomicznych zwłaszcza Chin, świadczą o stopniowym dezaktualizowaniu się mocarstwowej potęgi USA i systematycznym wchodzeniu w czasy „nowej wojny hegemonicznej” (terminologia Jerzego Modelskiego). W świetle tych danych, czego uczą wnioski z pozytywnie zweryfikowanych hipotez? Otóż, czym bardziej słabsze gospodarczo USA, tym mniej ten kraj jest aktywny politycznie i militarnie w perspektywie globalnej, a to powoduje wzrost liczby wojen na świecie (destabilizacja sytuacji międzynarodowej).

W przypadku Stanów Zjednoczonych ma miejsce jeszcze jedno negatywne zjawisko, co obrazują dwa poniższe rysunki (5 i 6). Mowa o przeobrażeniach społecznych i ideologicznych, które powodują, że udział wydatków przeznaczanych na zbrojenia, w ogólnej sumie wszystkich wydatków, ciągle spada. Jest to wynik zmian mentalno-ideologicznych dokonujących się w najbardziej rozwiniętych gospodarkach świata, które powodują wzrost interwencjonizmu państwowego, 
zwłaszcza w aspektach socjalnych, a to z kolei zmniejsza elastyczność i możliwość USA w aspektach realizacji potrzeb formułujących się na skutek systematycznie postępujących przemian geopolitycznych.

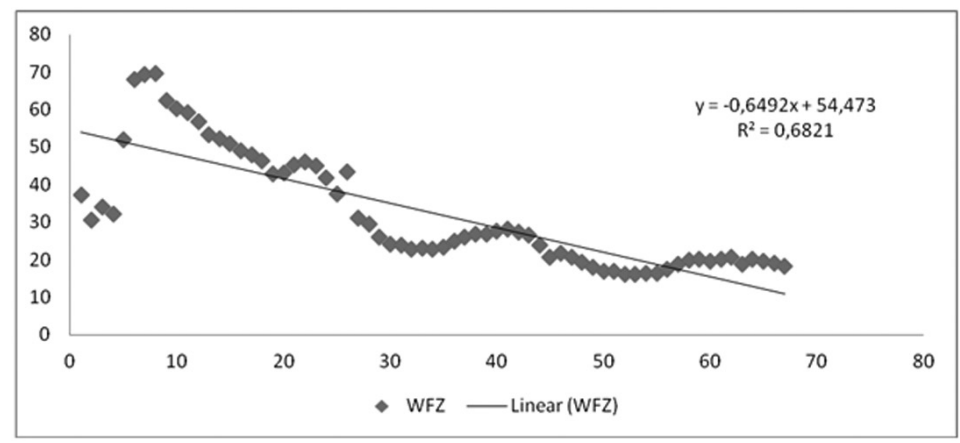

Rysunek 5. Trend zmian udziału budżetu Pentagonu w budżecie federalnym (1947-2013)

Źródło: opracowanie własne.

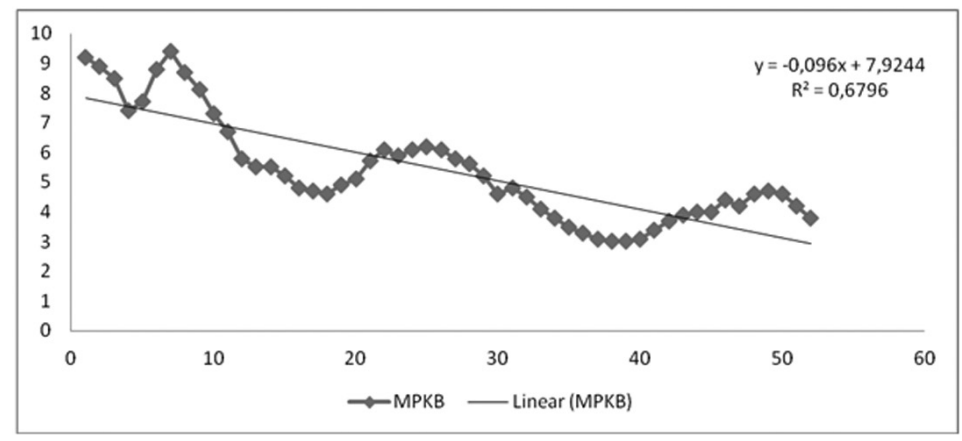

Rysunek 6: Trend zmian udziału polityki zbrojeniowej w wielkości realnej PKB (1947-2013)

Źródło: opracowanie własne.

Spójrzmy na ciąg wydarzeń historycznych od kryzysu finansowego z 2008 roku. Do władzy dochodzi Barak Hussein Obama. Uzyskanie mandatu społecznego przez tę osobę w dużej mierze ma swoją podstawę w hasłach przedwyborczych, które określić można jako „antywojenne” czy „defensywne”, ogólnie poświęcające politykę zagraniczną na rzecz problemów wewnętrznych. Przypuszczać można, że wybór Obamy na prezydenta USA ma swoje źródło w kryzysie finansowym. W czasie prezydentury Obamy Stany Zjednoczone stają się coraz mniej aktywne militarnie, gdzie np. uczestniczą tylko w 1/3 w wojnie w Libii, nie interweniują w Syrii (ogólnie przejawiają małą aktywność w ciągu wydarzeń „wiosny arabskiej”), wycofują się całkowicie z Iraku, mimo że to oznacza w pewnym względzie przegranie rywalizacji bliskowschodniej, zwłaszcza z Iranem, co do którego USA również w kwestii nuklearnej przyjmują bardziej uległą politykę. W tym też czasie wyraźnie widoczny jest nagły wzrost liczby wojen, zwłaszcza na Bliskim Wschodzie. 
W Europie sytuacja również stopniowo się destabilizuje, gdzie ma swój początek wojna na Ukrainie. Wyraźnie dostrzec można ofensywną postawę Chin, zwłaszcza w obszarze strategicznego obszaru, jakim jest Morze Południowo-Chińskie.

W świetle wyników prognozować można początek nowej historii powszechnej; historii, która nacechowana będzie systematycznym wzrostem liczby wojen, gdzie kumulacją tego trendu może być kolejna wojna globalna. Na dzień dzisiejszy przewidywać można co jedynie wzrost negatywnych wydarzeń i dalszy proces destabilizacji systemu polityki międzynarodowej.

\section{PODSUMOWANIE}

Powyższe badania stanowią element szerszego projektu badawczego starającego się zinterpretować procesy międzynarodowe poprzez pryzmat matematyki. Powyższe badania potwierdzają wysuniętą hipotezę, głoszącą, że stan gospodarki USA ma istotny wpływ na stan polityki zagranicznej tego supermocarstwowego kraju, czego ostatecznym efektem są istotne przeobrażenia międzynarodowe.

Procesy międzynarodowe są na tyle złożone, że na podstawie wyników modelu regresji liniowej nie jest możliwe zinterpretowanie całokształtu tych relacji, aby później na tle pozyskanej wiedzy dokonywać ścisłych i pewnych prognoz. Wobec czego na dzień dzisiejszy koniecznością staje się dalsze poszukiwanie zmiennych, ich kwantyfikowanie i wdrażanie w badania nowe i lepsze metody matematycznej analizy, nie koniecznie ze zakresu statystyki matematycznej.

W świetle wyników i znanych faktów historycznych i aktualnie dokonywujących się zdarzeń prognozować można dalszy proces postępującej destabilizacji międzynarodowej. Efekty tej destabilizacji są trudne do ostatecznego przewidzenia, gdzie może również zdarzyć się np. odwrócenie trendów. Jednakże autor wyraża sceptyczny pogląd w tej materii, uznając, że świat wchodzi w okres nowej wojny hegemonicznej (gdzie ostatnią nie była zimna wojna, tylko II wojna światowa), gdzie kształt tej wojny może być zupełnie odmienny od innych tym podobnych wydarzeń, głównie za sprawą broni nuklearnej. W świetle teorii cykli hegemonicznych można zaryzykować stwierdzenie, że ZSRR tak naprawdę zrezygnował z konfrontacji z USA (dwukrotnie, w 1962 r. i 1986 r.), uznając się za słabszego. Jak wiemy $z$ historii, ZSRR był - przynajmniej w perspektywie ekonomicznej - dużo słabszy od USA. Co stanie się teraz, gdy Chiny bezwzględnie dorównają, a nawet prześcigną Stany Zjednoczone? Sytuacja jest ogólnie bardzo złożona, dużo bardziej niż w czasach zimnej wojny. Otóż mają miejsce istotne przeobrażenia bliskowschodnie (również i w Afryce); ma miejsce poważne zachwianie równowagi sił pomiędzy różnymi graczami np. Grecją a Turcją, przy jednoczesnym wzroście aspiracji regionalno-mocarstwowych tego drugiego państwa; Rosja - kolos na glinianych nogach - broni się przed wewnętrznymi przeobrażeniami w sposób ofensywny, starając się najlepiej jak to tylko możliwe wykorzystać czas zmian, licząc na odbudowę swojej potęgi, myśląc w kategoriach 
głownie zimnowojennych i tym samym nie dostrzegając, że większym dla niej zagrożeniem mogą być Chiny niż USA; ma miejsce nowa wędrówka ludów; idee pierwotne Unii Europejskiej zostały wypaczone, region ten znalazł się w poważnym wielopłaszczyznowym kryzysie, gdzie obszar ten staje się strefą wpływów Niemiec, które systematycznie wypierają z Europy USA; natomiast Stany Zjednoczone są bardzo wyczerpane ostatnimi wojnami, kryzysem finansowym i polityką Obamy. Wszystko to świadczy o znaczących przeobrażeniach dokonywujących się aktualnie na świecie; przeobrażeniach, które - w świetle powyższych wyników badawczych - zapowiadają bardzo niespokojne czasy.

\section{BIBLIOGRAFIA}

1. Altair, http://www.altair.com.pl/

2. Defence24, http://www.defence24.pl/

3. Filipowicz L., Amerykańska ekonomia podaży, Wydawnictwo Poltext, Warszawa 1992.

4. Gaddis J. L., Strategie powstrzymywania, Książka i Wiedza, Warszawa 2007.

5. Gałganek A., Zmiany w globalnym systemie międzynarodowym: supercykle $i$ wojna hegemoniczna, Wydawnictwo Naukowe UAM, Poznań 1992.

6. Górecki T., Podstawy statystyki z przykładami w R, Wydawnictwo btc, Legionowo 2011.

7. Greń J., Statystyka matematyczna: Modele i zadania, Państwowe Wydawnictwo Naukowe, Warszawa 1976.

8. Ignatczyk W., Chromińska M., Statystyka: Teoria i zastosowanie, Wydawnictwo Wyższej Szkoły Bankowej, Poznań 1999.

9. Inside Gov, The Historical U.S. Federal Budget, http://federal-budget.insidegov.com/ (201506-19).

10. Kot M. S., Sokołowski A., Tablice statystyczne, Wydawnictwo Akademii Ekonomicznej w Krakowie, Kraków 2005.

11. Krupa M., Międzynarodowa statystyka zjawiska wojny w kontekście teorii stosunków międzynarodowych, „Horyzonty Polityki”, Akademia Ignatianum w Krakowie. Instytut Politologii, vol. 3(4), Kraków 2012, s. 243-266.

12. Krupa M., Model behawioralny określający wpływ aktywności militarnej USA na globalna ilość wojen, „Zeszyty Naukowe”, Akademia Obrony Narodowej, vol. 4(89), Warszawa 2012, s. 351-368.

13. Krupa M., Behawioralna analiza zjawiska wojny, „Społeczeństwo i Polityka”, Akademia Humanistyczna im. Aleksandra Gieysztora. Wydział Nauk Politycznych, vol. 3(32), Warszawa 2012, s. 179-204.

14. Krupa M., Matematyka w badaniach polemologicznych, „Civitas Hominibus - Rocznik Filozoficzno-Społeczny", Akademia Humanistyczno-Ekonomiczna w Łodzi, vol. 1(7), Łódź 2012, s. $125-140$.

15. Krupa M., The behavioral model determining the impact of the USA military activity on the global number of wars, "Scientific Quarterly", No. 4(89), Warsaw 2012, s. 260-276.

16. Krupa M., Model matematyczny relacji zachodzacych pomiędzy wzrostem gospodarczym a polityka zagraniczna na przyktadzie Stanów Zjednoczonych Ameryki Pótnocnej, „Nierówności Społeczne a Wzrost Gospodarczy”, Uniwersytet Rzeszowski. Katedra Teorii Ekonomii i Stosunków Międzynarodowych, Zeszyt 30, Rzeszów 2013, s. 323-347. 
17. Krupa M., Metody badawcze w obszarze polemologii, „Problemy społeczne, polityczne i prawne”, Uniwersytet Ekonomiczny w Krakowie, nr 903/2013, Kraków 2013, s. 17-34. (6 pkt. 2015 r.)

18. Krupa M., Krytyczna analiza teorii stosunków międzynarodowych Hansa Joachima Morgenthaua, ,Społeczeństwo i Polityka”, Akademia Humanistyczna im. Aleksandra Gieysztora. Wydział Nauk Politycznych, 3(36)/2013, Warszawa 2013, s. 103-119.

19. Krupa M., Nowożytna filozofia liberalizmu, konserwatyzmu i marksizmu w aspekcie polityki międzynarodowej i zjawiska wojny, „TEKA Komisji Politologii i Stosunków Międzynarodowych”, Polska Akademia Nauk, VIII/2013, Lublin 2013, s. 76-94.

20. Krupa M., Państwo Izraela - historia i prognoza polityczna, ekonomiczna i militarna 19602013, Część I - siła Izraela , „Bezpieczeństwo i Administracja. Zeszyty Naukowe WBN AON”, 3/(8) 2013, Warszawa 2013, s. 5-21.

21. Krupa M., Państwo Izraela - historia i prognoza polityczna, ekonomiczna i militarna 19602013, Część II - wojny Izraela, „Bezpieczeństwo i Administracja. Zeszyty Naukowe WBN AON", 4/(9) 2013, Warszawa 2013, ss. 68-80.

22. Krupa M., Cykl wojny a cykl koniunktury na przykładzie USA 1962-2007, „Myśl Ekonomiczna i Polityczna”, Kwartalnik Wydziału Ekonomii i Zarządzania Uczelni Łazarskiego, 1(44)2014, Warszawa 2014, s. 75-100.

23. Krupa M., Korelacja procesów politycznych i ekonomicznych na przyktadzie cykli koniunkturalnych USA, „Ekonomia”, Uniwersytet Ekonomiczny w Krakowie, nr 902/2014, Kraków 2014, s. $35-50$.

24. Krupa M., Model matematyczny relacji wzrostu gospodarczego USA z prowadzonymi przez ten kraj wojnami, „Ekonomia Międzynarodowa”, Uniwersytet Łódzki, nr 8, Łódź 2014, ss. 172-198.

25. Krupa M., Wpływ zadłużenia zagranicznego na koniunkturę gospodarcza na przykładzie krajów Ameryki Łacińskiej, „Finanse”, Uniwersytet Ekonomiczny w Krakowie, nr 4 (928), Kraków 2014, ss. 21-34.

26. Krupa M., Państwo Izraela - historia i prognoza polityczna, ekonomiczna i militarna 19602013, Część III - przyszłość Izraela, „Bezpieczeństwo i Administracja. Zeszyty Naukowe WBN AON", 1/(10) 2014, Warszawa 2014, ss. 47-58.

27. Krupa M., Ekonomia a wojna: perspektywa ekonometryczna, „Zarządzanie. Teoria i praktyka”, Wyższa Szkoła Menadżerska w Warszawie, nr 1/2014, Warszawa 2014, ss. 11-18.

28. Krupa M., Polemometria - matematyczna analiza zjawiska wojny, „TEKA Komisji Politologii i Stosunków Międzynarodowych", Polska Akademia Nauk, Lublin 2014.

29. Landreth H., Colander D. C., Historia myśli ekonomicznej, Wydawnictwo Naukowe PWN, Warszawa 2005.

30. Measuring Worth, Data Set, http://www.measuringworth.com/usgdp/ (2015-06-19).

31. Michałek K., Mocarstwo: Historia Stanów Zjednoczonych Ameryki Pótnocnej 1945-1992, Książka i Wiedza, Warszawa 1995.

32. Nye jr. J. S., Konflikty międzynarodowe: wprowadzenie do teorii i historii, Wydawnictwo Akademickie i Profesjonalne, Warszawa 2009.

33. Oyrzanowski B., Wspótczesna historia ekonomiczna Stanów Zjednoczonych w liczbach $i$ wykresach 1992, Wydawnictwo Platan, Kraków 1992.

34. Snarska A., Statystyka, Ekonometria, Prognozowanie: Ćwiczenia z Excelem 2007, Wydawnictwo Placet, Warszawa 2011.

35. Starzyński W., Statystyka praktyczna, Wydawnictwo Naukowe PWN, Warszawa 2005.

36. The World Bank, Explore. Create. Share: Development Data, http://databank.worldbank.org/ data/home.aspx (2015-06-19). 
37. U.S. Government Publishing Office, Economic Report of the President, http://www.gpo.gov/ fdsys/browse/collection.action?collectionCode=ERP (2015-06-19).

38. United States Department of Labor: Bureau of Labor Statistics, Data Base, Tables \& Calculators by Subject,http://data.bls.gov/timeseries/LNU04000000?years_option=all_years\&periods_option=specific_periods\&periods=Annual+Data (2015-06-19).

39. Zając K., Zarys metod statystycznych, Państwowe Wydawnictwo Ekonomiczne, Warszawa 1994.

40. Zeliaś A. (red.), Statystyka matematyczna w zastosowaniach, Akademia Ekonomiczna w Krakowie, Kraków 1996.

41. Zeliaś A., Metody statystyczne, Polskie Wydawnictwo Ekonomiczne, Warszawa 2000.

\title{
MODEL OF THE LINEAR REGRESSION IN THE BOTH FORECAST AND RESEARCH OF THE DEPENDENCE IN THE UNITED STATES ECONOMIC AND FINANCIAL RELATIONS AND THE PENTAGON BUDGET
}

\begin{abstract}
This research constitute the continuation processes of the verification of three research hypotheses, which aspire to the role of the social right, and exactly determining entitlements repeatable mechanisms of international reports. In its being a rightness is verifying the following article of the first hypothesis which is stating that the dynamic growth in the economy in the USA is preceding the height of political and military activity of this country, taking place in the international space.

So far research was carried out in the temporal space of 1962-2007 years, in this case the temporal space was widened for years 1947-2013. A space was also widened quota, where analysis in this case is operating on the new variable.
\end{abstract}

Key words: war, USA, growth in the economy, trade cycle, regression, statistics 